ORIGINAL ARTICLE

\title{
Influence of crop residue ration supplementation on the attainment of puberty and postpartum reproductive activities of Red Sokoto goats
}

\author{
B. S. Malau-Aduli ${ }^{1}$, L. O. Eduvie ${ }^{2}$, C. A. M. Lakpini ${ }^{2}$ and A. E. O. Malau-Aduli ${ }^{2,3}$ \\ 1 Department of Animal Science, Ahmadu Bello University, Zaria, Nigeria; \\ 2 National Animal Production Research Institute, Ahmadu Bello University, Zaria, Nigeria and \\ 3 Department of Animal Breeding and Reproduction, National Institute of Livestock and Grassland Science, Tsukuba, Ibaraki, Japan
}

\author{
Correspondence \\ A. E. O. Malau-Aduli, School of Agricultural \\ Sciences, Faculty of Science, Engineering and \\ Technology, The University of Tasmania, \\ Private Bag 54, Hobart, Tasmania 7001, \\ Australia. Tel: +61-3-6226-2717; \\ Fax: +61-3-6226-2642; \\ E-mail: aduli40@yahoo.co.uk
}

Received: 1 July 2003;

accepted: 16 March 2004

\section{Summary}

The general objective of this study was to come up with an appropriate, affordable and locally available crop residue supplementation package that would enhance reproductive performance in small ruminants. Specifically, 28 Red Sokoto weaner does between 3 and 4 months of age weighing between 2 and $3 \mathrm{~kg}$ were used in the first experiment to determine the influence of crop residue supplementation on age and weight at puberty as determined by blood progesterone levels. In the second experiment, another 28 adult does ( $\geq 2$ years old) of the same breed in the same flock with lactation numbers between 1 and 3 were used to determine the length of postpartum acyclic period. In both experiments, a $3 \times 2$ factorial experimental design comprising three dietary supplements (A, B, C) at two feeding levels ( $1 \%$ and $2 \%$ of body weight) fed in addition to a basal diet of Digitaria smutsii hay and natural pasture ad libitum with an unsupplemented negative control group (D) and four goats per treatment was utilized. In ration A, a conventional concentrate supplement consisting of maize, wheat offal, cottonseed cake and bonemeal was utilized; in rations $\mathrm{B}$ and $\mathrm{C}$, the supplement consisted of guinea-corn bran, cowpea husk and groundnut haulms; and maize offal, groundnut shells and groundnut haulms respectively. Unsupplemented (ration D) weaner does reached puberty at a later age and had lighter body weights than all the others. Weaner does on ration $2 \mathrm{~A}$ (concentrate fed at $2 \%$ of body weight) attained puberty at the earliest age and heaviest body weight, although the age at puberty was not significantly different from those on rations $1 \mathrm{~A}$ (concentrate fed at $1 \%$ body weight), IC and 2C. Blood progesterone profiles before and after puberty ranged from 0.05 to $9.0 \mathrm{ng} / \mathrm{ml}$, respectively, and was highest in does fed rations $\mathrm{A}$ and $\mathrm{C}$ and least in the unsupplemented does. The mean interval between kidding and initiation of ovarian activity was $54.28 \pm 17.61$ days and the mean interval between kidding and conception was $63.04 \pm 25.34$ days. Only $25 \%$ of the unsupplemented does conceived again during the period under study compared with $100 \%$ in rations $1 \mathrm{~A}, 2 \mathrm{~A}, 1 \mathrm{C}$ and $2 \mathrm{C} ; 75 \%$ in ration $2 \mathrm{~B}$ and $50 \%$ in ration $1 \mathrm{~B}$. It was concluded that implementation of supplementary feeding in the dry season improves reproductive performance in the Red Sokoto doe. Furthermore, ration $\mathrm{C}$, a crop residue-based ration, was a suitable dry season supplementation alternative to the expensive conventional concentrate ration for the smallholder goat farmer in the subhumid tropics of Nigeria. 


\section{Introduction}

In Nigeria, the Red Sokoto goat is the most widespread and well-known breed of goat with the largest population of approximately $50 \%$ of the total goat population of the country (Osinowo and Abubakar, 1988; Osinowo, 1992). The Red Sokoto goat is found throughout the subhumid and semiarid zones of Nigeria. It is a medium-sized breed with reddish-brown coat colour with a mature average live weight of $30 \mathrm{~kg}$ kept for its milk, meat and skin. Detailed descriptions of its milk composition (MalauAduli and Anlade, 2002; Malau-Aduli et al., 2003a), herd size (Gefu and Adu, 1982), production (Mathewman, 1980; Otchere et al., 1987), lactation (Ehoche and Buvanendran, 1983) and reproductive performance (Adu and Ngere, 1979; Malau-Aduli et al., 2003b, 2004) have been documented. However, the production of these animals is limited by genetic and environmental factors such as nutrition, disease and their interactions that lead to poor reproductive performance. Efforts must therefore be made to identify and eliminate constraints that reduce the contribution of these goats to the socioeconomic development of the farmers. Supplementations using residues such as groundnut haulms and shells (Adu and Lakpini, 1983; Ikhatua and Adu, 1984; Alawa and Umunna, 1993; Malau-Aduli et al., 2003c) and cowpea vines and husks (Alhassan et al., 1984) have been documented, but none of these involved reproductive performance. There are several locally available feed resources such as crop residues and forage trees that could be used to supplement grazing, particularly during the dry season when animals lose weight. Currently, smallholder goat farmers in the subhumid zone of Nigeria have no practical dry season feed supplementation packages to guide them in efficient and affordable utilization of crop residues. Therefore, this study was undertaken with the broad aim of conducting feed supplementation trials to determine how locally available crop residues might be used to improve the animals reproductive performance. The specific objectives were to determine:

1 Age and weight at onset of puberty in Red Sokoto weaner does.

2 The effect of supplementation on the postpartum reproductive activities of the Red Sokoto doe.

3 A better crop residue ration that can be recommended for optimum reproductive performance to smallholder goat farmers in the subhumid zone of Nigeria.

\section{Materials and methods}

Animals and their management

In the first experiment to determine the influence of crop residue supplementation on age and weight at puberty, 28 nulliparous Red Sokoto weaner does between 3 and 4 months of age weighing between 2 and $3 \mathrm{~kg}$ at the Small Ruminant Research Programme, National Animal Production Research Institute (NAPRI) Shika, Nigeria, were used. The location of Shika and management practices have been described in detail elsewhere (Malau-Aduli et al., 2003a). The animals were weighed at 1-week intervals. Twice-weekly blood samples were obtained by jugular venipuncture to determine progesterone concentration. In the second experiment, another 28 adult does ( $\geq 2$ years old) of the same breed in the same flock with lactation numbers between 1 and 3 were used to determine the length of postpartum acyclic period. Does were all naturally bred. Commencing from the second week of kidding, milk samples were obtained on a twiceweekly basis to determine progesterone concentration until the does were confirmed to be pregnant. In both experiments, a $3 \times 2$ factorial experimental design comprising three rations $(\mathrm{A}, \mathrm{B}, \mathrm{C})$ and two feeding levels ( $1 \%$ and $2 \%$ of body weight) of four goats each was utilized. Prior to the experiment, all animals were dewormed and dipped in Asuntol (Bayer Nigeria, Lagos, Nigeria) acaricide solution against ectoparasites. Routine health checkups were performed on the flock by animal health personnel on a regular basis in line with management protocols at the Experimental Unit. The duration of the first and second experiments was 214 and 120 days respectively.

\section{Treatment rations}

Ration A was the conventional concentrate and animals in treatment $1 \mathrm{~A}$ were fed at $1 \%$ of their body weight and their counterparts on ration $2 \mathrm{~A}$ were fed at $2 \%$ of their body weight (both groups constituted the positive control). Rations $\mathrm{B}$ and $\mathrm{C}$ were the two test rations. Animals in treatments $1 \mathrm{~B}$ and $2 \mathrm{~B}$ were offered ration $\mathrm{B}$ at $1 \%$ and $2 \%$ of their body weights, respectively, while those in treatments $1 \mathrm{C}$ and $2 \mathrm{C}$ had were offered ration $\mathrm{C}$ at $1 \%$ and $2 \%$ of their body weights respectively. Does in treatment $\mathrm{D}$ had access to only the basal diet of natural pasture and Digitaria hay (thus constituting the negative control or the unsupplemented group). 


\section{Feeds and feeding}

Each group was fed its ration in the morning (08:0010:00 hours) before being released into the paddocks to graze on natural pastures and Digitaria smutsii hay (basal diet) until 18:00 hours after which they were returned to the holding pens. The composition of the grazed pasture has been described in detail elsewhere (Lakpini et al., 1997). The rations in all the groups had been subjected to digestibility trials prior to being fed to the experimental animals. The laboratory and experimental procedures for the digestibility trial involving the rations and Digitaria hay, determination of the chemical composition of the ingredients and economic analyses of the rations have been described in detail previously (Malau-Aduli et al., 2003a).

\section{Determination of age and weight at puberty}

The age at which the does within the treatment groups attained puberty was the sum of the period of dietary supplementation and of the non-supplemented period from birth. Body weights of the weaner doe were recorded weekly throughout the experimental period. The growth rate for each group was calculated as final weight minus initial weight divided by the number of days.

\section{Collection of blood samples and hormonal assay}

Blood samples $(10 \mathrm{ml})$ from each weaner doe were collected twice a week by jugular venipuncture using test tubes. The blood samples were allowed to coagulate within $2 \mathrm{~h}$ of collection and the sera decanted into plastic tubes and stored at $-20{ }^{\circ} \mathrm{C}$ until assayed. Blood sampling continued until progesterone profiles indicated that a weaner doe had reached puberty. A weaner doe was deemed to have reached puberty when the first elevation in plasma progesterone concentration above $0.1 \mathrm{ng} / \mathrm{ml}$ was followed by at least two elevated concentrations in the next three consecutive samples (Fasanya et al., 1992). It was assumed that the first of such rises in progesterone concentration was preceded by an ovulation 3-4 days earlier.

Serum progesterone concentration was determined by radioimmunoassay procedure using the solidphase coated tube system employing ${ }^{125} \mathrm{I}$ as tracer supplied in kit form by the Joint FAO/IAEA Division, Agriculture Laboratory, Siebersdof. The assay procedure was as follows.

To antibody coated tubes, $100 \mu \mathrm{l}$ of standard $(0.1-$ $40 \mathrm{ng} / \mathrm{ml}$ ) of sample and $1 \mathrm{ml}$ buffered $\left[{ }^{125} \mathrm{I}\right]$-labelled progesterone solution was added. The mixture was incubated for $3 \mathrm{~h}$ at room temperature, the liquidphase discarded (centrifugation is not required) and the radioactivity bound to the antibody-coated tube counted. The immunogen used to raise the antibody and radioiodinated progesterone (tyrosine methyl ester) are both $11 \alpha$-linked conjugates. The cross-reactivity, $3.8 \%$, was with $11 \alpha$-hydroxy progesterone (Kubasik et al., 1984). The sensitivity of the assay defined as twice 'th' standard deviation of the zero standard was $0.08 \mathrm{ng} / \mathrm{ml}$. The within and between assay coefficients of variation were $8.5 \%$ and $9.5 \%$ respectively. The potencies of the samples were estimated using a linear logit-log dose-response curve.

\section{Determination of the length of postpartum acyclic period}

Twenty-eight multiparous does ( $\geq 2$ years), which had just kidded between October and November 1998, were used for this study. Breeding was by natural service only in which four bucks were released into the paddocks with the does each day while grazing, and they were withdrawn at the end of the study. Does that persistently showed progesterone values of $2 \mathrm{ng} /$ ml or higher were assumed to be pregnant. Milk samples for progesterone concentration determination were collected twice weekly. Sodium azide tablets were used as milk preservatives, the milk samples were centrifuged and stored at $-20{ }^{\circ} \mathrm{C}$ until assayed. Milk progesterone concentrations were determined by radioimmunoassay technique using the FAO/IAEA kit (Joint FAO/IAEA Division, Agriculture Laboratory, Siebersdorf, Austria). Milk sampling commenced from the second week of kidding and continued until does was confirmed pregnant. The same criterion as that for the initiation of cyclicity at puberty was used to judge initiation of ovarian activity postpartum.

\section{Statistical analysis and experimental design}

Statistical analysis using the general linear models procedure (PROC GLM) of sas (1987) in a $3 \times 2$ factorial (three rations and two feeding levels) analysis to test for significant differences between mean values was carried out using the model below:

$$
Y_{i j k l}=\mu+R_{i}+F_{j}+(R F)_{i j}+\mathrm{bw}+e_{i j k}
$$

where, $Y_{i j k}=$ dependent variable of the $k$ th doe on the $i$ th ration and the $j$ th feeding level, $\mu=$ the overall mean, $R_{i}=$ fixed effect of the $i$ th ration $(i=1,3)$, $F_{j}=$ fixed effect of the $j$ th feeding level $(j=1,2)$, $(R F)_{i j}=$ interaction between the $i$ th ration and $j$ th 
feeding level, bw = initial body weight fitted as a covariate, and $e_{i j k l}=$ random error associated with each record with a mean of 0 and variance $\sigma_{e}^{2}$.

Primary and secondary interactions of fixed effects with initial body weight were also tested but later dropped from the model as all the interactions were not significant, partly because all the animals were, as much as possible, balanced for initial weight and age at the start of the experiment. The Tukey test was used for mean separation where significant differences were established between treatments.

\section{Results}

Chemical composition of the experimental rations and feed intake

The chemical compositions of the individual feed ingredients and the experimental rations have been published in detail elsewhere (Malau-Aduli et al., 2003a) and would only be summarized here. Ration A, the conventional concentrate supplement consisted of maize, wheat offal, cottonseed cake and bonemeal. In rations $\mathrm{B}$ and $\mathrm{C}$, the supplement consisted of guinea-corn bran, cowpea husk and groundnut haulms; and maize offal, groundnut shells and groundnut haulms respectively. The unsupplemented negative control group (D) consisted of D. smutsii hay and natural pasture.

The highest crude protein (CP) content was obtained in ration $\mathrm{A}$ and the lowest in ration $\mathrm{D}$ (17\% and $5 \%$ respectively) while rations $\mathrm{B}$ and $\mathrm{C}$ both contained $10 \% \mathrm{CP}$ each. The highest neutral detergent fibre (NDF), acid detergent fibre (ADF) and lignin contents of $75 \%, 49 \%$ and $10 \%$, respectively, were found in the hay constituent of ration $\mathrm{D}$; and the lowest values of $40 \%, 20 \%$ and $5 \%$, respectively, in ration $\mathrm{A}$. It was also observed that supplementation increased the intake and digestibility of all the nutrients and increasing the level of supplementation also resulted in increased dry matter (DM) and CP intakes of all the experimental rations, with these increases being significant $(\mathrm{p}<0.05)$ and similar for rations $\mathrm{A}$ and $\mathrm{C}$, whereas animals on ration $\mathrm{B}$ had similar values to the unsupplemented group (Table 1).

\section{Age and body weight at puberty}

Results of Expt 1 revealed that supplementation had a significant effect $(\mathrm{p}<0.01)$ on age and weight at puberty weaner does (Table 2 ). The does showed a first rise in serum progesterone concentration, indicating attainment of puberty, at an average age of

Table 1 Mean nutrient intake, apparent digestibility coefficients and cost of the experimental rations

\begin{tabular}{|c|c|c|c|c|c|c|c|c|}
\hline Ration & $1 \mathrm{~A}$ & $2 \mathrm{~A}$ & $1 \mathrm{~B}$ & $2 \mathrm{~B}$ & $1 \mathrm{C}$ & $2 \mathrm{C}$ & $\mathrm{D}$ & SEM \\
\hline \multicolumn{9}{|c|}{ Nutrient intake (kg/day) } \\
\hline DMI & $0.24^{b}$ & $0.47^{a}$ & $0.21^{b c}$ & $0.30^{a b}$ & $0.23^{b}$ & $0.42^{a}$ & $0.15^{\mathrm{c}}$ & \pm 0.02 \\
\hline $\mathrm{CPI}$ & $0.044^{a}$ & $0.087^{a}$ & $0.012^{b}$ & $0.017^{b}$ & $0.032^{a}$ & $0.072^{a}$ & $0.009^{b}$ & \pm 0.01 \\
\hline \multicolumn{9}{|c|}{ Apparent digestibility of nutrients (\%) } \\
\hline DM & $84.3^{a}$ & $83.0^{a}$ & $62.5^{d}$ & $60.5^{e}$ & $75.8^{b}$ & $67.8^{c}$ & $56.4^{f}$ & \pm 2.84 \\
\hline $\mathrm{CP}$ & $90.6^{a}$ & $89.2^{a}$ & $69.5^{d}$ & $65.5^{\mathrm{e}}$ & $82.7^{b}$ & $78.1^{\mathrm{c}}$ & $48.4^{f}$ & \pm 3.07 \\
\hline NDF & $69.5^{\mathrm{a}}$ & $66.6^{b}$ & $62.1 c^{d}$ & $61.9^{d}$ & $65.9^{b}$ & $63.7^{c}$ & $60.1^{\mathrm{e}}$ & \pm 3.23 \\
\hline ADF & $51.7^{a}$ & $49.8^{a}$ & $43.9^{b c}$ & $42.8^{c}$ & $46.1^{b}$ & $44.4^{\mathrm{bc}}$ & $42.3^{b c}$ & \pm 5.01 \\
\hline
\end{tabular}

Data from Malau-Aduli and colleagues (2003c)

\begin{tabular}{lllc}
\hline Ration & Age (days) & Body weight $(\mathrm{kg})$ & Growth rate $(g /$ day)* \\
\hline 1A & $167.5 \pm 12.5^{\mathrm{a}}$ & $11.5 \pm 0.5^{\mathrm{abc}}$ & $120 \pm 10.2^{\mathrm{c}}$ \\
2A & $160.0 \pm 12.5^{\mathrm{a}}$ & $12.7 \pm 0.5^{\mathrm{a}}$ & $170 \pm 10.2^{\mathrm{a}}$ \\
1B & $235.3 \pm 12.5^{\mathrm{b}}$ & $10.0 \pm 0.5^{\mathrm{c}}$ & $30 \pm 10.2^{\mathrm{f}}$ \\
2B & $217.5 \pm 12.5^{\mathrm{b}}$ & $10.3 \pm 0.5^{\mathrm{c}}$ & $40 \pm 10.2^{\mathrm{e}}$ \\
1C & $177.5 \pm 12.5^{\mathrm{a}}$ & $11.0 \pm 0.5^{\mathrm{bc}}$ & $90 \pm 10.2^{\mathrm{d}}$ \\
2C & $161.3 \pm 12.5^{\mathrm{a}}$ & $12.0 \pm 0.5^{\mathrm{ab}}$ & $150 \pm 10.2^{\mathrm{b}}$ \\
D & $288.0 \pm 12.5^{\mathrm{c}}$ & $10.0 \pm 0.5^{\mathrm{c}}$ & $20 \pm 10.2^{\mathrm{g}}$ \\
\hline
\end{tabular}

Table 2 Effect of ration supplementation on age, weight and growth rate $( \pm$ SEM) at puberty in Red Sokoto does

Mean values within columns bearing different superscripts differ significantly $(p<0.05)$

* Growth rate $=$ (Body weight at puberty - Initial body weight)/Number of days 
$201.0 \pm 50.5$ days and at an average live weight of $11.1 \pm 1.4 \mathrm{~kg}$. Table 2 also shows that does on ration $\mathrm{D}$ (the unsupplemented group) attained puberty at a later age $(288.0 \pm 12.5$ days $)$ and at a lower body weight $(10.0 \pm 0.5 \mathrm{~kg})$ than others. Does on ration $2 \mathrm{~A}$ attained puberty at the earliest age $(160.0 \pm 12.5$ days $)$, but this was not significantly different from those on rations $1 \mathrm{~A}, 1 \mathrm{C}$ and $2 \mathrm{C}$. There were significant differences $(\mathrm{p}<0.01)$ in body weight at puberty (Table 2) with does on ration $2 \mathrm{~A}$ having the heaviest weight at puberty $(12.8 \pm 0.5 \mathrm{~kg})$ while does on rations $1 \mathrm{~B}, 2 \mathrm{~B}$ and $\mathrm{D}$ had the lightest weight $(10.0 \pm 0.5)$. There were significant differences $(p<0.05)$ in the growth rates of the animals; those on ration $2 \mathrm{~A}$ had the highest growth rate of $170 \mathrm{~g} /$ day followed by those on ration 2C with $150 \mathrm{~g} /$ day. The least growth rate was obtained in the unsupplemented group (ration D).

The mean serum progesterone concentration for each treatment group was low during the pre-pubertal stages of development, ranging from non-detectable to $0.1 \mathrm{ng} / \mathrm{ml}$. Peripheral blood progesterone concentrations after attainment of puberty were high in all treatment groups ranging from 1 to $8 \mathrm{ng} / \mathrm{ml}$, except for those does on ration $1 \mathrm{~B}$ and the unsupplemented group which had only values ranging from 1 to $4 \mathrm{ng} / \mathrm{ml}$ (Fig. 1 ).

\section{Length of postpartum acyclic period}

In Expt 2 with the adult does, the interval between kidding and initiation of ovarian activity as indicated by the first rise in milk progesterone concentration followed by regular cyclicity was significantly $(\mathrm{p}<0.01)$ affected by supplementation (Table 3$)$. Does on ration $2 \mathrm{~A}$ resumed cyclicity (34.8 \pm 2.7 days) earlier than all the other treatment groups, but this was not significantly different from their counterparts on ration $2 \mathrm{C}(41.7 \pm 2.7$ days $)$. The unsupplemented does had the longest period of acyclicity $(84.3 \pm 2.7$ days $)$. The postpartum interval to conception was significantly $(p<0.01)$ influenced by supplementation, with the unsupplemented does conceiving much later $(109.5 \pm 3.8$ days $)$ than the other treatment groups (Table 3 ). On the contrary, does on ration $2 \mathrm{~A}$ conceived earlier than the other groups (37.2 \pm 3.8 days) although they were not significantly different from rations $2 \mathrm{C}$ and $1 \mathrm{~A}$ which conceived at $44.0 \pm 3.8$ and $47.3 \pm 3.8$ days respectively. The results also showed that for each ration, does on $2 \%$ of body weight diets resumed cyclicity and conceived earlier than those fed the rations at $1 \%$ of their body weight.
Conception rates for the does in the seven treatment groups are shown in Table 4 . At the end of the first month after kidding, conception rates were $25 \%, 50 \%, 0 \%, 0 \%, 25 \%, 50 \%$ and $0 \%$ in does on rations 1A, 2A, 1B, 2B, 1C, 2C and D respectively. By the fourth month, almost all the does had conceived except those on rations $1 \mathrm{~B}, 2 \mathrm{~B}$ and $\mathrm{D}$, which recorded only $50 \%, 75 \%$ and $25 \%$ conception rates respectively. Two does in ration $\mathrm{D}$ resumed cyclicity as evidenced by the milk progesterone concentration after kidding, but one of them did not conceive till the end of the study, indicating silent oestrus.

\section{Discussion}

In spite of rations $\mathrm{B}$ and $\mathrm{C}$ being isocaloric and isonitrogenous, better intake and digestibility were recorded in animals on ration $C$. This could possibly be attributed to a number of factors-like palatability differences of the rations. It was observed during the experiment, which goats completely consumed all of rations $\mathrm{A}$ and $\mathrm{C}$, but took less of ration $\mathrm{B}$ and very little of the hay. These differences in intake on different supplementation regimes were direct behavioural reactions to the palatability differences of the rations. Also, the lower digestibility of ration $\mathrm{B}$ compared with $\mathrm{C}$ could partly be attributed to the high fibre and lignin contents of the former supplement. Furthermore, ration $\mathrm{C}$ seemed to have produced better intakes and digestibilities in the animals, possibly due to the processing and composition of the rations. For instance, the groundnut shells fed to the animals were crushed before inclusion into the ration. This must have aided to improve their consumption and digestibility. Although ration B contained groundnut haulms, the combination of guinea-corn bran and cowpea husk which had low CP percentages (Alhassan et al., 1984), must have reduced the intake and digestibility of the ration. Ration $\mathrm{C}$ contained maize offal which has very low fibre content (Alawa and Umunna, 1993), groundnut haulms which have been demonstrated to be better quality roughages than $D$. smutsii hay and contain adequate protein to maintain ruminants without any form of supplementation during the periods of feed scarcity (Ikhatua and Adu, 1984).

The weaner does attained puberty at an average age of 201 days (Table 2). Age at puberty depended more on body growth rather than age because the unsupplemented does (ration D group) were the oldest and lightest at puberty and had the lowest growth rate, indicating that inadequate supply or poor quality of feed adversely affects the growth rate 

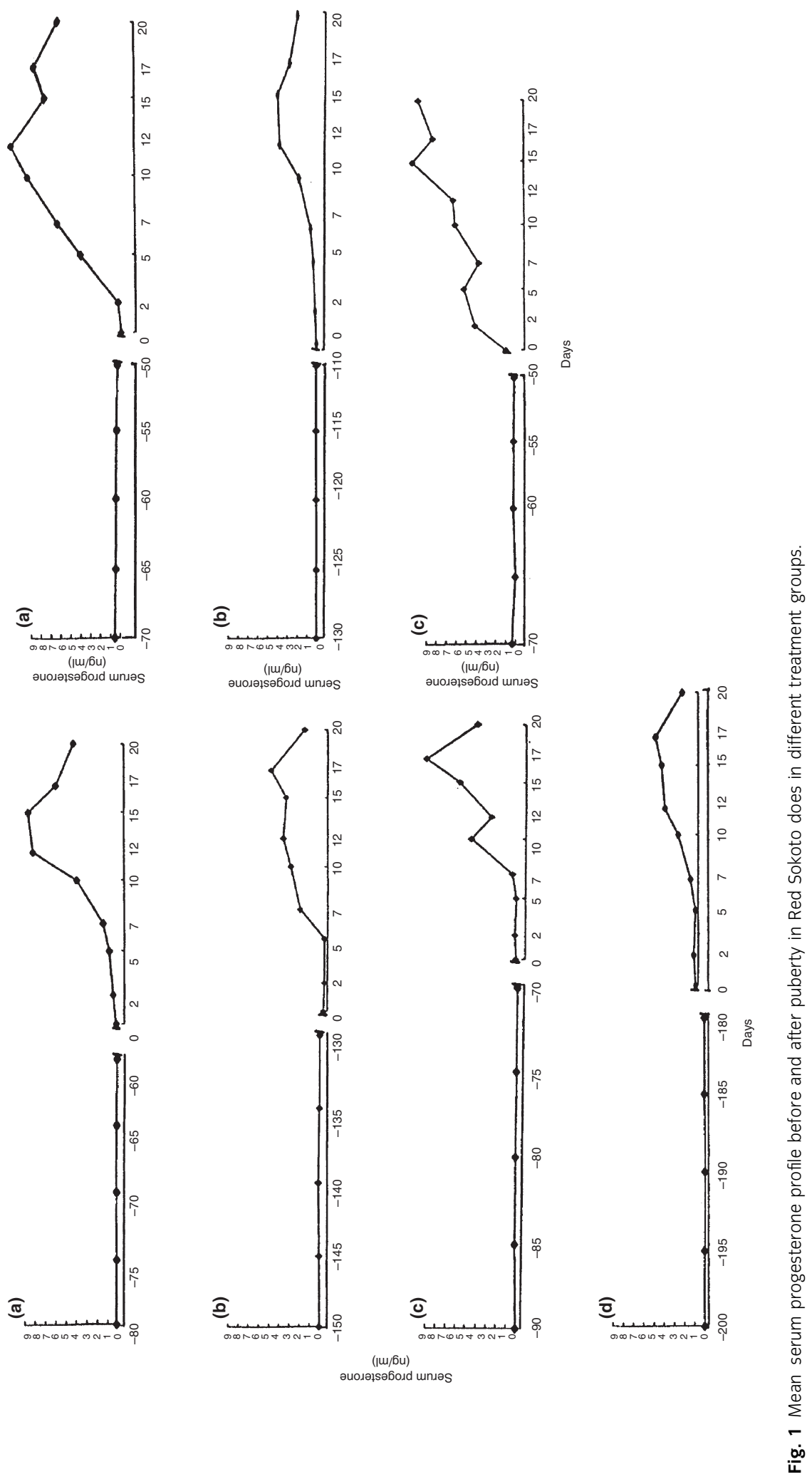
Table 3 Effect of ration supplementation on postpartum reproductive performance of Red Sokoto does

\begin{tabular}{lll}
\hline & $\begin{array}{l}\text { Postpartum interval to } \\
\text { first milk progesterone } \\
\text { rise (days) }\end{array}$ & $\begin{array}{l}\text { Postpartum interval } \\
\text { to conception (days) }\end{array}$ \\
\hline Ration & $43.8 \pm 2.7^{\mathrm{e}}$ & $47.3 \pm 3.8^{\mathrm{e}}$ \\
2A & $34.8 \pm 2.7^{f}$ & $37.2 \pm 3.8^{\mathrm{e}}$ \\
1B & $69.7 \pm 2.7^{\mathrm{b}}$ & $82.3 \pm 3.8^{\mathrm{b}}$ \\
2B & $61.5 \pm 2.7^{\mathrm{c}}$ & $70.7 \pm 3.8^{\mathrm{c}}$ \\
1C & $44.3 \pm 2.7^{\mathrm{e}}$ & $50.2 \pm 3.8^{\mathrm{d}}$ \\
2C & $41.7 \pm 2.7^{\mathrm{f}}$ & $44.0 \pm 3.8^{\mathrm{e}}$ \\
D & $84.3 \pm 2.7^{\mathrm{a}}$ & $109.5 \pm 3.8^{\mathrm{a}}$ \\
\hline
\end{tabular}

Mean values within columns bearing different superscripts are significantly different $(p<0.01)$

of animals thereby resulting in their attainment of sexual maturity at a late age. The present study showed that within does on the same ration type, increasing the level of supplementation to $2 \%$ level of their body weight resulted in the attainment of puberty at an earlier age and heavier body weights than their counterparts fed at $1 \%$ level (Table 2). The difference could probably be due to increased feed intake associated with the $2 \%$ level of inclusion.

From literature, the major factors controlling the onset of puberty are body weight and growth rate rather than age (Joubert, 1963; Boyd, 1977; McDonald, 1980; Mancio et al., 1982). Studies by Penzhorn (1975), Shokamoto and colleagues (1975) in cattle and Fasanya and colleagues (1992) in goats, showed that nutritional level affected age at puberty but did not influence body weight changes. In contrast, the present study demonstrates that nutritional level affects both age and body weight at puberty (Table 2). However, this observation agrees with the reports of Oyedipe and colleagues (1982) in Zebu heifers and Boulanouar and colleagues (1995) in sheep. The pre- sent study showed that does on the conventional concentrate ration (with very high energy and protein levels) attained puberty at about the same time as does on ration C. This confirms that although poor nutrition delays puberty, very high levels of feeding do not necessarily result in earlier puberty than that obtained with adequate diets. Does on ration B attained puberty later just like the unsupplemented group. This indicates that ration $\mathrm{B}$ did not meet the requirements of the animals for reproduction, and it may be due to poor palatability, low voluntary intake and low digestibility of the ration. The observed lower serum progesterone concentrations in the does on rations $\mathrm{IB}$ and $\mathrm{D}$ confirms the effect of poor nutrition on the neuro-endocrine system as reported by Lamond (1970), Salisbury and colleagues (1978) and Rhind and colleagues (1986).

Parturition is usually followed by a period of ovarian inactivity and sexual quiescence before reproductive cycles recommence. The length of this period is variable and can be influenced by several environmental factors including nutrition (Dunn et al., 1969; Van Niekerk, 1982; Butler and Smith, 1989). Results obtained in the present study on the length of acyclicity in adult do confirm the report by Whitman (1975) in that unsupplemented does resumed cyclicity later than the supplemented groups. Some of the animals in the unsupplemented group remained acyclic even up to 4 months after kidding, probably as a result of limiting dietary nutrients in the feed consumed. Rutter and Randel (1984) also observed that postpartum interval to conception in beef cattle heifers decreased with increasing levels of nutrient intake. These findings, on the other hand, contradict the report of Bellows and Short (1978) who demonstrated that prepartum nutrition is more important than postpartum nutrition in determining the length of postpartum interval in cattle.
Table 4 Effect of ration supplementation on postpartum conception rate in Red Sokoto does

\begin{tabular}{llllll}
\hline \multicolumn{5}{c}{ Number pregnant* } \\
\cline { 3 - 6 } Ration & $\begin{array}{l}\text { Number } \\
\text { of does }\end{array}$ & $\begin{array}{l}\text { 1 month } \\
\text { postpartum }\end{array}$ & $\begin{array}{l}\text { 2 months } \\
\text { postpartum }\end{array}$ & $\begin{array}{l}\text { 3 months } \\
\text { postpartum }\end{array}$ & $\begin{array}{l}\text { 4 months } \\
\text { postpartum }\end{array}$ \\
\hline 1A & 4 & $1(25)$ & $2(50)$ & $3(75)$ & $4(100)$ \\
2A & 4 & $2(50)$ & $4(100)$ & $4(100)$ & $4(100)$ \\
1B & 4 & $0(0)$ & $0(0)$ & $0(0)$ & $2(50)$ \\
2B & 4 & $0(0)$ & $1(25)$ & $1(25)$ & $3(75)$ \\
1C & 4 & $1(25)$ & $2(50)$ & $2(50)$ & $4(100)$ \\
2C & 4 & $2(50)$ & $3(75)$ & $4(100)$ & $4(100)$ \\
$D$ & 4 & $0(0)$ & $0(0)$ & $0(0)$ & $1(25)$ \\
\hline
\end{tabular}

* Figures in brackets represent percentages 
The conception rates observed in the experimental animals showed that rations $\mathrm{A}$ and $\mathrm{C}$ had the highest proportions of pregnant does during the period investigated. The does on ration D (unsupplemented group) had the lowest conception rate. This observation indicates that nutrition has a significant effect on growth and conception rates in ruminants. The same trend of poor reproductive performance in the weaner does on ration $\mathrm{B}$ was also observed in the adult does. This is a further confirmation that ration $\mathrm{B}$ is an unsuitable dry-season supplementation package for Red Sokoto does because of its high content of indigestible nutrients. The present study confirms the importance of postpartum supplementation in determining the length of postpartum interval to conception.

Improvement in reproductive rate is more readily achievable by paying attention to the environment of which nutrition is an important component. The present study clearly demonstrates the impact of nutrition on reproduction of Red Sokoto does in the subhumid tropics. From this study, it was also clearly evident that ration $\mathrm{C}$ elicited as much favourable responses in the reproductive performance of the animals as ration A (the positive control, conventional concentrate ration which may be too expensive for the local farmer to purchase). In conclusion, dietary supplementation of Red Sokoto does with ration $\mathrm{C}$ (cheap crop residue feed resource) is recommended to Nigerian smallholder goat farmers, as this would yield just as good results in terms of attainment of puberty and postpartum reproductive performance, as the expensive conventional concentrate during the long dry periods of the year.

\section{Acknowledgement}

The authors gratefully acknowledge the support of the International Atomic Energy Agency (IAEA) Vienna, Austria, in funding this project through the provision of hormonal assay kits and chemical reagents. The technical assistance in ELISA protocols by Mr Joe Iyayi of the Animal Reproduction Laboratory of the National Animal Production Research Institute (NAPRI), Ahmadu Bello University (ABU) Shika-Zaria, Nigeria, is appreciated. Authors equally acknowledge with thanks, the technical assistance of Messrs Jimoh Lawal, Jerry Luka, S. Afolabi and C.F. Abolude of the NAPRI Small Ruminant Research Programme. Also grateful to the Director, NAPRI, ABU Zaria, for permission to publish this work.

\section{References}

Adu, I. F.; Lakpini, C. A. M., 1983: Nigerian J. Anim. Prod. 10,110 .

Adu, I. F.; Ngere, L. O., 1979: World Rev. Anim. Prod. 15, 51.

Alawa, J. P.; Umunna, N. N., 1993: J. Anim. Prod. Res. 13, 63.

Alhassan, W. S.; Ehoche, O. W.; Adu, I. F.; Obilara, T. A.; Kallah, M. S., 1984: Crop Residue Potential of Agricultural Development Projects: Nutritive Value and Residue Management. NAPRI Annual Report, National Animal Production Research Institute, Shika, Nigeria, pp. 35-45.

Bellows, R. A.; Short, R. E., 1978: J. Anim. Sci. 46, 1522.

Boulanouar, B.; Ahmed, M.; Klopfenstein, T.; Brink, D.; Kinder, J., 1995: Anim. Reprod. Sci. 40, 229.

Boyd, H., 1977: Vet. Rec. 11, 150.

Butler, W. R.; Smith, R. D., 1989: J. Dairy Sci. 72, 767.

Dunn, T. G.; Ingalls, J. E.; Zimmerman, D. R.; Wiltbank, J. N., 1969: J. Anim. Sci. 29, 719.

Ehoche, O. W.; Buvanendran, V., 1983: World Rev. Anim. Prod. 19, 19.

Fasanya, O. O. A.; Molokwu, E. C. I.; Eduvie, L. O.; Dim, N. I., 1992: Anim. Reprod. Sci. 29, 157.

Gefu, J. O.; Adu, I. F., 1982: World Rev. Anim. Prod. 18, 25. Ikhatua, U. I.; Adu, I. F., 1984: J. Anim. Prod. Res. 4, 145. Joubert, D. M., 1963: Anim. Breed. Abstr. 31, 295.

Kubasik, N. P.; Hallauer, G. D.; Brodows, R. G., 1984: Clin. Chem. 30, 284.

Lakpini, C. A. M.; Balogun, B. I.; Alawa, J. P.; Onifade, O. S.; Otaru, S. M., 1997: Anim. Feed Sci. Technol. 67, 197.

Lamond, D. R., 1970: Anim. Breed. Abstr. 38, 359.

Malau-Aduli, A. E. O.; Anlade, Y. R., 2002: Anim. Sci. J. 73, 541 .

Malau-Aduli, B. S.; Eduvie, L. O.; Lakpini, C. A. M.; Malau-Aduli, A. E. O., 2003a: Livestock Prod. Sci. 83, 63.

Malau-Aduli, B. S.; Eduvie, L.; Lakpini, C.; Malau-Aduli, A. E. O., 2003b: Anim. Sci. J. 74, 195.

Malau-Aduli, B. S.; Eduvie, L.; Lakpini, C.; Malau-Aduli, A. E. O., 2003c: Anim. Sci. J. 74, 89.

Malau-Aduli, B. S.; Eduvie, L.; Lakpini, C.; Malau-Aduli, A. E. O., 2004: Reprod. Nutr. Dev. 44, 111.

Mancio, A. B.; Viana, J. A. C.; Azavedo, N. A.; Rehfeld, O. A. M.; Ruas, J. R. M.; Amaral, R., 1982: Arq. Escol. Vet. Univ. Fed. Minas Gerais 34, 573.

Mathewman, R. W., 1980: Trop. Anim. Health Prod. 12, 234.

McDonald, L. E., 1980: Veterinary Endocrinology and Reproduction. Lea and Febiger, Philadelphia, 560 pp.

Osinowo, O. A., 1992: Livestock Planning, Monitoring, Evaluation and Coordinating Unit Livestock Sub-sectoral Review: Working Paper on Small Ruminants. Consultant - O.A. Osinowo, National Animal Produc- 
tion Research Institute, Ahmadu Bello University Zaria, Nigeria, April 1992, pp. 12-14.

Osinowo, O. A.; Abubakar, B. Y., 1988: Appropriate Breeding Strategies for Small Ruminant Production in West and Central Africa. OAU/IBAR, Nairobi, Kenya.

Otchere, E. O.; Ahmed, H. U.; Adenowo, I. K.; Kallah, M. S.; Bawa, E. K.; Olorunju, S. A. S.; Voh, A. A., 1987: World Anim. Rev. 64, 50.

Oyedipe, E. O.; Osori, D. I. K.; Akerejola, O.; Saror, D., 1982: Theriogenology 18, 525.

Penzhorn, E. J., 1975: Agroanimalia 7, 49.

Rhind, S. M.; Leslie, I. D.; Gunn, R. G.; Doney, J. M., 1986: Anim. Prod. 43, 101.

Rutter, L. M.; Randel, R. D., 1984: J. Anim. Sci. 58, 265.
Salisbury, G. W.; Van demark, N. L.; Lodge, J. R., 1978: Management factors that affect reproductive efficiency of the bull. In: Physiology of Reproduction and Artificial Insemination of Cattle (G. W. Salisbury, ed.). W.H. Freeman, San Francisco, pp. 733-789.

Sas, 1987: Statistical Analysis System. SAS Institute, Cary, North Carolina, USA.

Shokamoto, S.; Imaizumi, E.; Shijimaya, K., 1975: Anim. Breed. Abstr. 43, 676.

Van Niekerk, A., 1982: S. Afr. J. Anim. Sci. 12, 383.

Whitman, R. W., 1975: Weight Change, Body Condition and Beef-cow Reproduction. PhD Dissertation, Colorado State University, Fort Collins, USA. 